\title{
Groundwater Recharge Estimation Using WetSpass Modeling in Upper Bilate Catchment, Southern Ethiopia
}

\section{Bitsiet Dereje $^{1^{*}}$ and Dessie Nedaw ${ }^{2}$}

${ }^{1}$ Department of Water well Drilling and Supervision, South Design and Construction Enterprise, P.O. Box 116, Hawassa, Ethiopia (*bitsuan4je@ gmail.com).

${ }^{2}$ School of Earth Sciences, CNCS, Addis Ababa University, P.O. Box 1176, Addis Ababa, Ethiopia.

\begin{abstract}
The study area, upper Bilate catchment, is strongly dependent on groundwater like other rural catchments in the country. The main objective of this work is to quantify the amount of groundwater recharge in upper Bilate catchment. Recharge was estimated using physically based distributed recharge model called WetSpass. As input to the model precipitation, potential evapotranspiration, temperature and wind speed were estimated using data collected from meteorological stations located within the catchment and nearby areas. The physical environmental data including land use, soil type, and groundwater depth were collected from field and existing maps. Slope and topography map were generated from Shuttle Radar Topographic Mission elevation data. Using the model the mean annual recharge of the catchment was found to be $9.4 \%$ of the precipitation whereas the direct runoff was found to be $20 \%$ of the precipitation. The study area is characterized by lower groundwater recharge relative to surface runoff due to the effect of impermeable soils, morphology of the land and land use/land cover of the study area. The western and northern parts of the area are identified as recharging zone and the central and southern part are discharge zone. The groundwater recharge zoning map was validated using base flow separation method and also compared with previous groundwater recharge works of the study area. This study revealed that the groundwater recharge estimation using WetSpass model is reasonable and useful for quantification of annual groundwater recharge with spatial and seasonal variation and also capable in the identification of groundwater recharge zones in the area under study.
\end{abstract}

Keywords: Runoff, Evapotranspiration, Groundwater, WetSpass, Bilate catchment, Ethiopia.

\section{INTRODUCTION}

Groundwater is a precious resource of limited extent. In order to ensure its judicious use, proper evaluation is required. Groundwater has emerged to be one of the major sources of potable water for various purposes in both urban and rural areas. The role of groundwater for water supply and irrigation is increasing with time in Ethiopia. This is becoming more important as the reliability of surface water and rain fed agriculture is threatened by the changing climatic condition.

Sustainability of a groundwater -based water supply or irrigation is strongly influenced by the recharge mechanism and amount. This is particularly true in arid and semi-arid areas, 
where groundwater recharge assessment is a key challenge in determining sustainable yield of aquifers (Yongxin and Beekman, 2003).

Estimation of groundwater recharge involves different methods including water-balance method, isotope technique, or by multiplying the magnitude of water-level fluctuations in wells with the specific yield of the aquifer material as well as using conservative geochemical tracers like chloride. But, commonly groundwater recharge is determined to a large extent as an imbalance at the land surface between precipitation and evaporative demand (Gebrerufael Hailu, 2008). One of the main challenges in groundwater recharge estimation is accurately estimating its distributed values in a hydrologically and geographically variable catchment. The advent of Geographic Information Systems (GIS), physical-based hydrologic modeling, enabled to address some of the problems. WetSpass, a GIS based model, was built as a physically based methodology for estimation of the long-term average, spatially varying, water balance components: surface runoff, actual evapotranspiration and groundwater recharge (Batelaan and De Smedt, 2001, 2007).

Like in many areas in Ethiopia, upper Bilate catchment in southern Ethiopia is one of the areas where groundwater is the main source of water supply. Hence, this forces the local communities to use groundwater not only for drinking but also for other domestic and in some cases for irrigation purposes. Though, the groundwater is recharged from precipitation and utilization of the resource is going on, understanding of the recharge amount and its areal distribution as well as the temporal and spatial variation of the other water balance components is not clear. Considering the high population growth rate and the increased dependence on groundwater, lack of proper knowledge of groundwater recharge will create a major problem for the sound and appropriate groundwater management in the catchment. Hence, estimation of rates of groundwater recharge in the area is crucial for sustainable utilization of the resource as well as its protection against pollution and depletion. This paper tries to address this issue.

\section{DESCRIPTION OF THE STUDY AREA}

\subsection{Location, Topography and Soil Type}

The study area is found in the southern nations, nationalities and people region (SNNPRG) about $230 \mathrm{~km}$ southwest of Addis Ababa and $130 \mathrm{~km}$ northwest of the regional town Hawassa. This catchment covers portion of four SNNPRG Zones and one special Woreda; Hadiya, Gurage, Silte, and Kenbata Tembaro zones and Halaba Special Woreda. The river catchment starts from 
the highlands of Gurage and Hadiya Zones and flows southward to the river gauging station in Halaba Special Woreda. Geographically, the study area extends $07^{\circ} 30^{\prime} 35^{\prime}$ ' $\mathrm{N}$ to $08^{\circ} 06^{\prime} 55^{\prime}$ ' $\mathrm{N}$ and $37^{\circ} 48^{\prime} 17^{\prime}$ 'E to $38^{\circ} 12^{\prime} 45^{\prime}$ ' E, having an area of about $2,075 \mathrm{~km}^{2}$ and a perimeter of $295 \mathrm{~km}$ (Figs $1 \&$ 2). Elevation in the catchment ranges from 1,700 to 3,325 m. a. s .l.

The physiographic set up of the study area is the result of volcano- tectonic, rifting, erosion and deposition processes. The catchment can be divided into three physiographic regions: the rift, the transitional escarpment and highlands. Soils in the area are classified in to five classes based on their texture (FAO, 2003), they are - silty loam, clay loam, silty clay, loam and sandy clay soils.

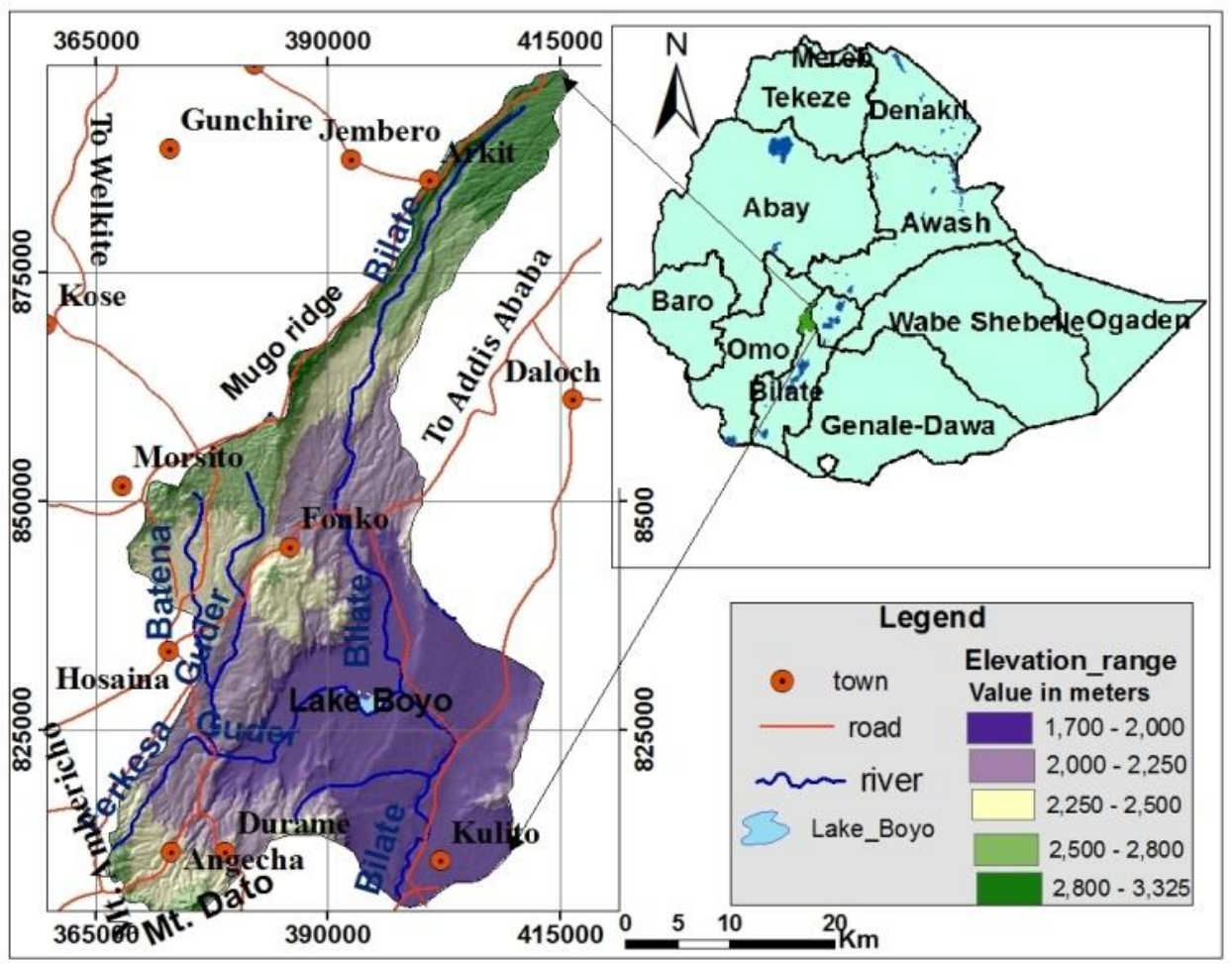

Figure1. Location map of the study area.

\subsection{Landuse/ landcover, Climate and Vegetation}

Land use is an important characteristic of the runoff process that affects infiltration, erosion, and evapotranspiration. The main crops grown in the area are wheat, barley, maize, sorghum and different types of grains and vegetables. In terms of areal coverage the important land cover units are cultivated land, woodland, bare land, grassland, perennial marsh and open water body, Lake Boyo (Fig 3). Cultivated land accounts $52.8 \%$, woodland $25 \%$ which includes areas covered by eucalyptus trees and different types of vegetation and bare land 14\%. Grass land, shrub, and bush 
about $6 \%$ and perennial marsh $2 \%$ and open water $0.19 \%$ of the catchment which is dominated by Aloe and Acacia species (Fig 3).

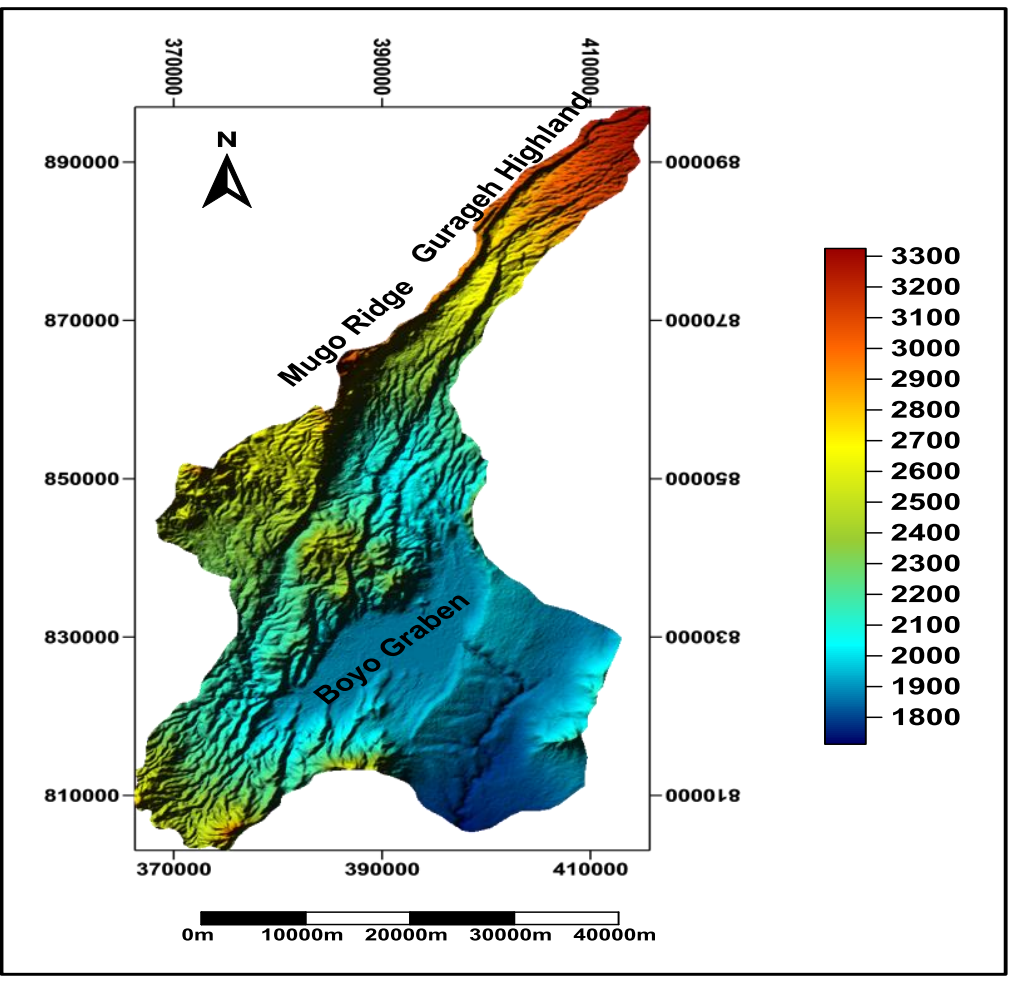

Figure 2. Three dimensional visualization of upper Bilate catchment.

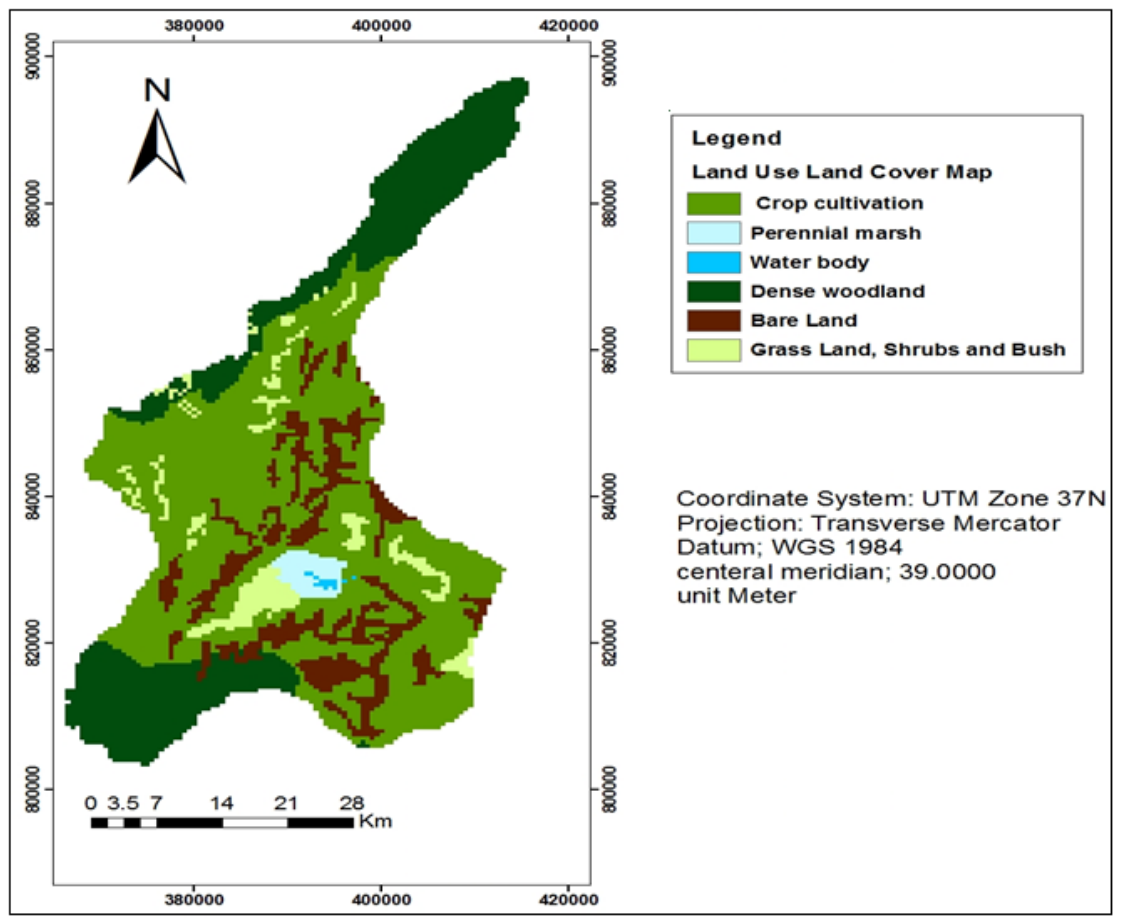

Figure 3. Landuse/Landcover map of upper Bilate catchment. 


\subsection{Geological and Hydrogeological Set up}

Bilate catchment lies within the Main Ethiopian Rift. The rift floor and escarpments are highly faulted due to volcanic eruption. Geologically, the area is mainly covered by volcanic rocks that belong to- Nazereth Group, Dino Formation, Pleistocene volcanic, younger sediments, and recent alluvial and lacustrine deposits. Hydrogeological conditions of upper Bilate catchment are mainly controlled by the lithologies, geological structures and geomorphology. Geological structures like faults, fractures, graben, and horst play a principal role in groundwater movement and permeability of the catchment. The Rift floor is affected by several faults that form smaller horst and graben structures. Many springs in the area discharge into the land surface from mainly along the fault and fracture zones of the area at higher elevations within the low lands and/or graben. These have mostly high rates in the escarpments and most are scattered along fault scarps in the west and north of the area (Fig 4).

In the upper Bilate catchment, the western and northern parts are recharging zones and the central and southern parts are the discharging zones. Whereas, the area just southeast of Boyo plain is categorized under deep groundwater zone (Sinteyeh Legessa, 2009).The study area comprises of a variety of volcanic and volcano-sedimentary rocks that belong to different ages and stratigraphic sequence.

\subsubsection{Nazareth Group}

It consists of ash flow, ignimbrites and unwelded tuff. This formation widely covered the northern and some portion of western part of the study area including Angacha, Doyogena and Lemo Woredas. The alteration product of the ignimbrite, ash flow and pumacious pyroclastics are exposed at quarry sites around Anlemo Woreda which have been used for construction materials.

This part of the catchment acts as recharge zone with several springs emerging out from this area and the aquifers are characterized as intergranular and fissured aquifers.

\subsubsection{Dino Formation}

It is associated with unwelded pyroclastics mainly tuff, ignimbrite, pumice and waterlain pyroclastics with occasional intercalated lacustrine beds. This formation is widely exposed at quarry sites and at Bilate river bed of Shashogo and Alaba special woredas. Many wells in the catchment are drilled in this formation. It is characterized as having moderately productive fissured aquifers. 


\subsubsection{Volcanic Rocks (Recent)}

Mainly exposed along the south eastern part of the area around Halaba it comprises enormous accumulation of pyroclastic products of pumice ash and obsidian. This formation has a high permeability related to intergranular porosity. Its hydrogeologic significance is limited because of its area extent and geomorphologic position.

\subsubsection{The Lacustrine Sediments}

These are located in topographical low areas, where the rainfall amount is low, thus recharge comes from high runoff in the escarpments and around Boyo plain. This deposit is characterized by intergranular porosity with a relatively high productivity.

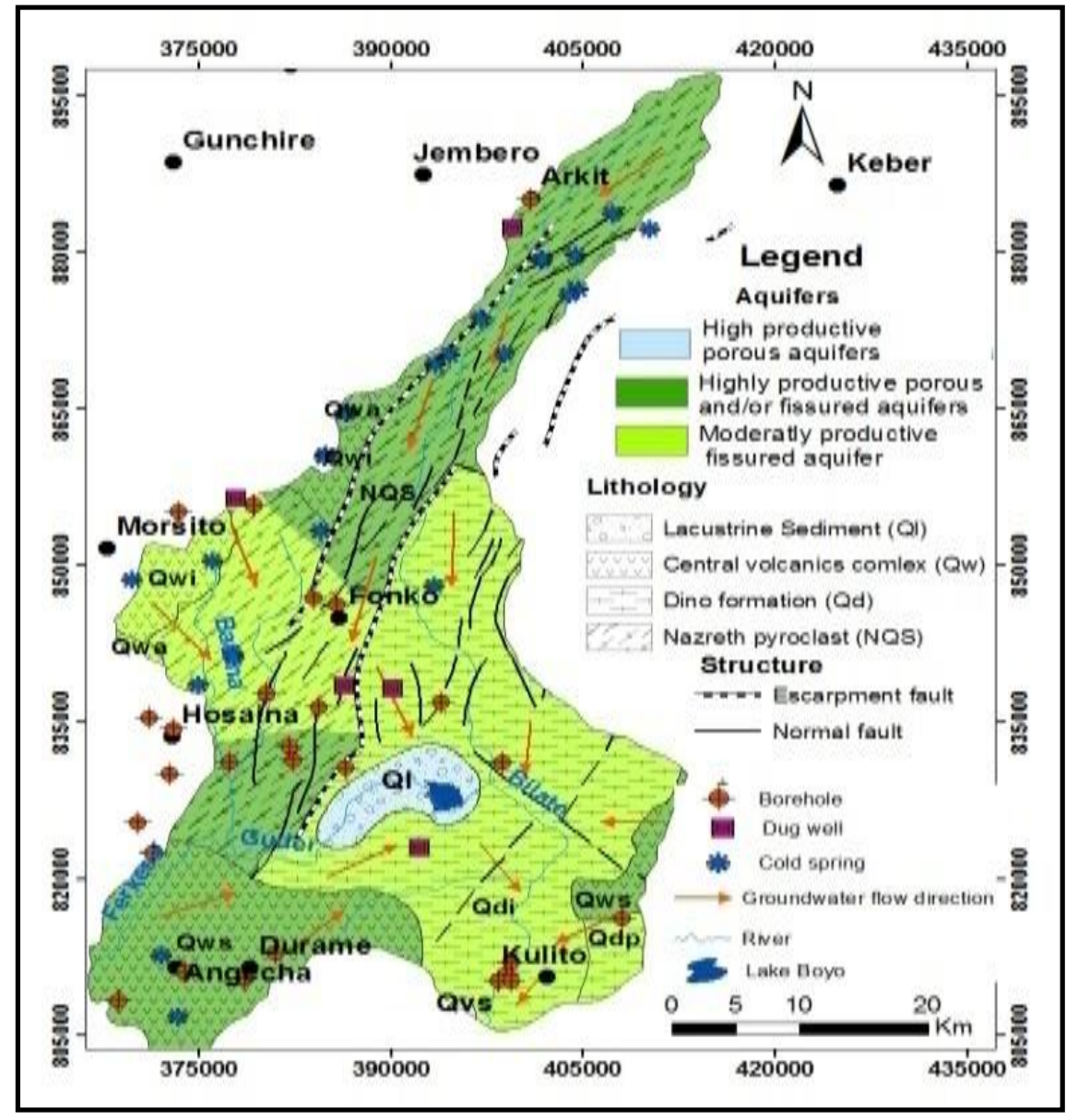

Figure 4. Hydrogeological map of upper Bilate catchment (KefalaTilahun and Jirisima, 2012).

\section{METHODOLOGY}

Geological and hydrogeological report and maps are collected from Geological Survey of Ethiopia (GSE) (2012) and Addis Ababa University. Meteorological data were collected from 
National Meteorological Agency (NMA) from ten stations having 20 to 30 years records. Groundwater- related data including groundwater level are collected 10 to 20 years from South Water Works and Construction Enterprise (SWWCE), Regional, Zonal and Woreda water resource development offices. Field investigation was conducted to verify existing geological map and to modify land use and soil maps from global sources. Moreover, static water level measurements of accessible wells were conducted in order to generate groundwater contour map. The data were analyzed using MS-Excel, Arc-view GIS 3.2, GIS ArcMap 10, Global Mapper 11 and Surfer 10. Finally, the WetSpass modeling was used to estimate groundwater recharge. WetSpass modeling was developed for temperate regions by Batelaan and DeSmedt (2001, 2007), which has different climatic and land conditions compared to the tropics; some input parameters were modified and used to apply it in tropical region. In temperate region, summer and winter have six month each while in Ethiopia summer contains four months and winter covers eight months. So, to apply the WetSpass for upper Bilate catchment, input of the meteorological grid map was done using eight months of winter and four months of summer. Also, modified summer and winter land-use parameter tables were used. Two types of inputs are required so as to run the WetSpass model: Parameter tables (dbf data) and grid map. ArcView (version 3.2) together with its spatial analyst extensions were used in order to prepare these input parameters. Then, these tables were added to the maps as attribute. The tables of runoff related parameters contain runoff coefficient, slope and soil type for each corresponding landuse. Topography, slope, landuse, soil, evapotranspiration, rainfall, temperature, wind speed and groundwater level maps were prepared. Hence, the topographic grid map and the slope map were derived from SRTM and ArcView 3.2. Temperature, precipitation and wind speed parameters were prepared using the available meteorological data collected from national meteorological agency. WetSpass model tries to estimate groundwater recharge mainly from water balance components not taking into consideration the role of geological structures such as faults and fractures in rock exposures.

\section{RESULTS AND DISCUSSION}

\subsection{Hydro-meteorological Data Analysis}

In the broadest sense, hydrology addresses the occurrence, distribution, movement of all waters of the earth (Fetter, 2001). Hence, to estimate hydrologic balance for a given basin, each of the 
hydro-meteorological elements has to be quantified. Accordingly, rainfall, actual evapotranspiration, runoff and groundwater recharge are estimated.

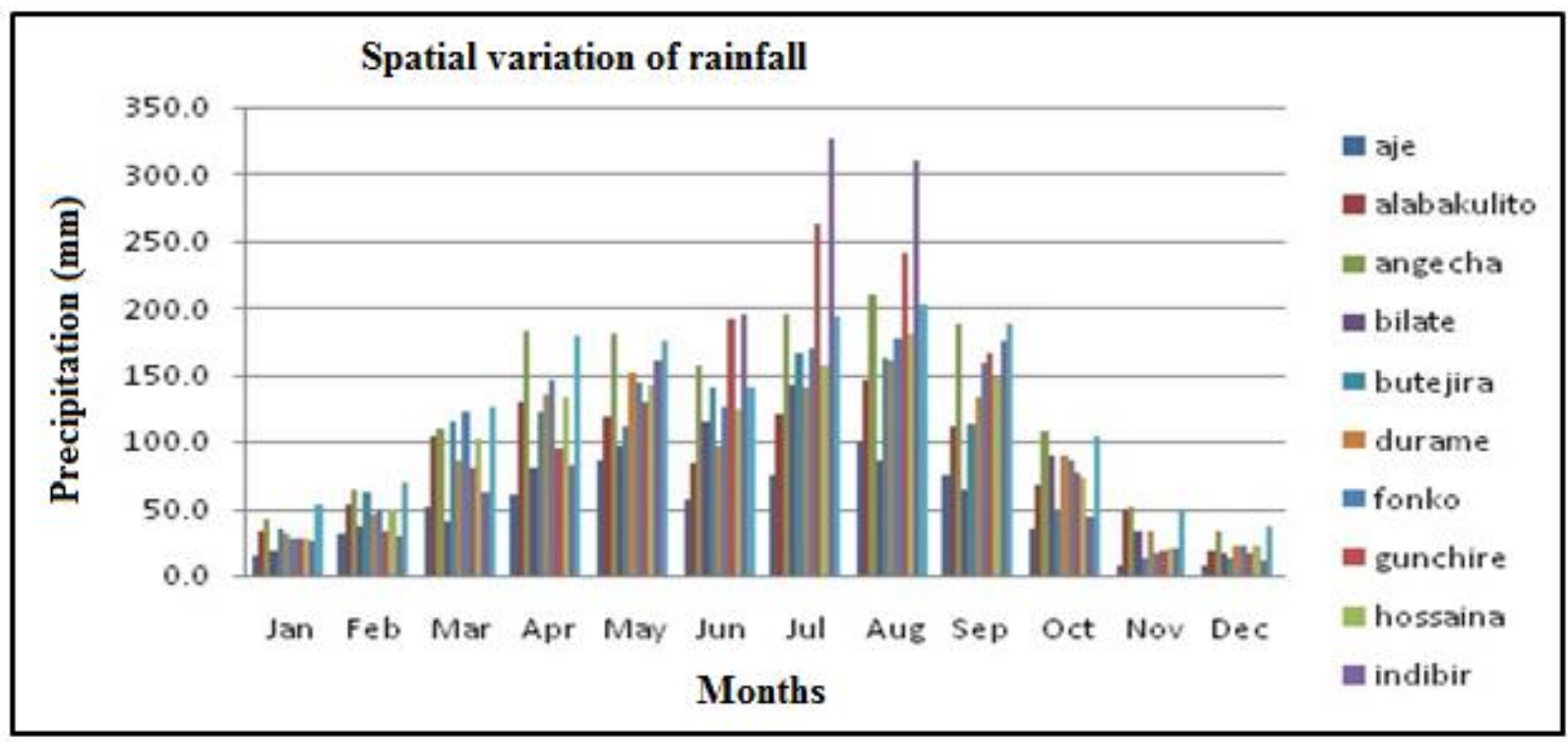

Figure 5. Long term mean monthly precipitation in the study area (1971-2014).

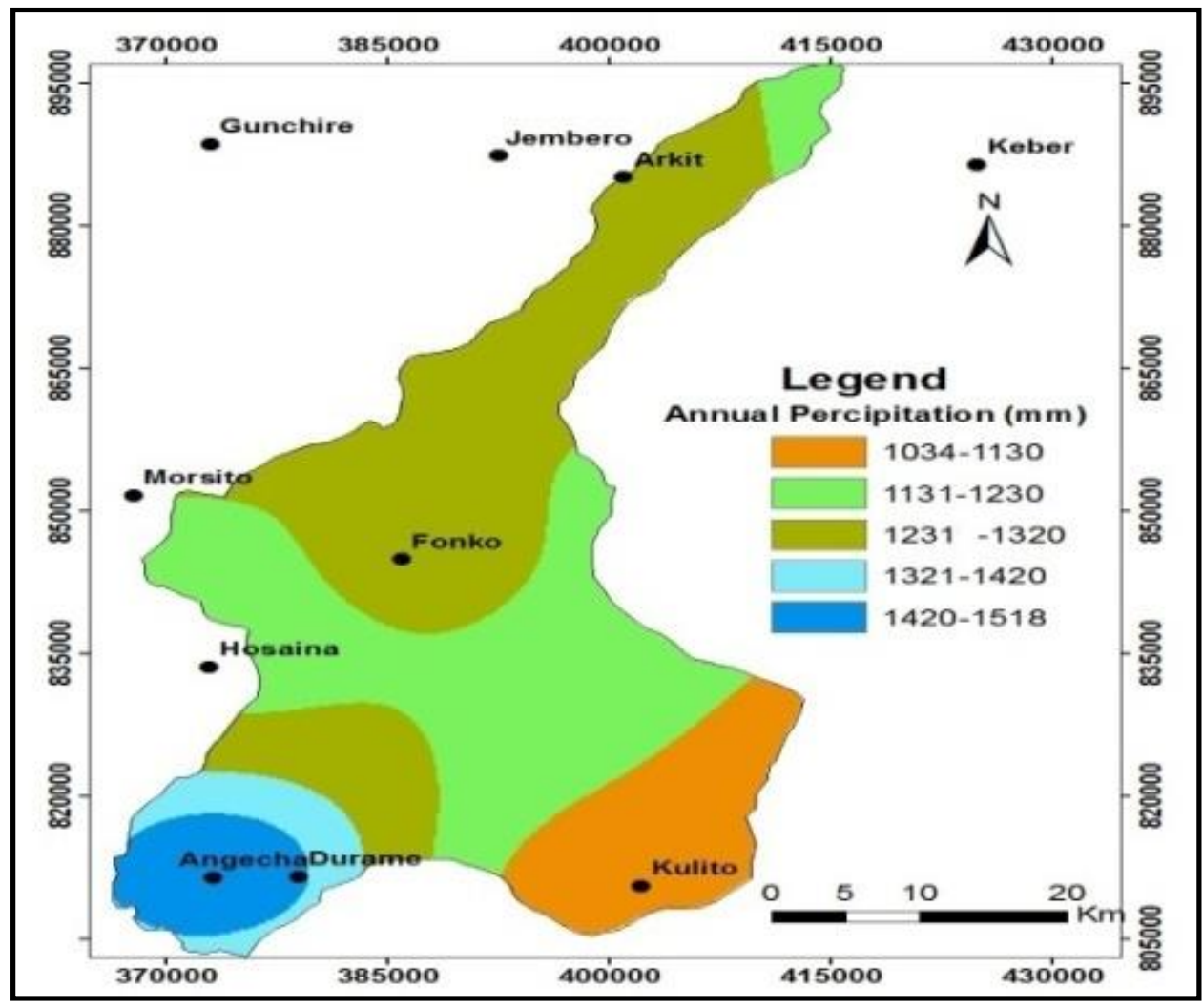

Figure 6. Rain fall distribution map of upper Bilate catchment. 


\subsubsection{Rainfall}

Rainfall distribution analysis and its temporal variability which was done based on rainfall data obtained in and near the study area is characterized by unimodal (single peak) rainfall pattern. The main rainy months are June, July, August and September, which are considered as the summer season in the modeling. The distributed rainfall map is generated using interpolation tool by Krigging in ArcGIS spatial analyst module using the point rainfall data from the meteorological stations. Accordingly the annual mean rainfall is $1232 \mathrm{~mm}$ (Fig 5 \& 6).

\subsubsection{Potential Evapotranspiration}

Evapotranspiration is an important parameter in water budget which abstracts water from the system and controls the soil moisture content, groundwater recharge and stream flow components of a certain basin. Regarding to the calculation of potential evapotranspiration there are several approaches and formulas. Among these methods the Penman combination formula has been used widely and helps to provide a more realistic evaluation of moisture content of a certain catchment (Shaw, 1994). Accordingly the monthly PET of Upper Bilate catchment is calculated using the Penman formula. The monthly results are subdivided in to two main seasons (4 months of summer and 8 months of winter). Finally, the summed PET values of each season are converted to spatially distributed grid maps. The grid maps of PET for both seasons are incorporated with other input parameters in WetSpass model to estimate the recharge as well as actual evapotranspiration (AET).

\subsection{Outputs of WetSpass Modeling}

Annual and seasonal groundwater recharge, evapotranspiration and surface runoff are the main outputs of the WetSpss model. A brief description of these output are given below.

\subsubsection{Annual Actual Evapotranspiration}

The annual evapotranspiration was calculated by WetSpass as a sum of evaporation from bare land, transpiration of the vegetated cover, interception loss by vegetation and evaporations of open water body. Actual evapotranspiration is one components of water balance to determine groundwater recharge of upper Bilate catchment using the WetSpass model. About $860 \mathrm{~mm}$ of water is lost through evapotranspiration from the catchment. This accounts for $69.8 \%$ of the catchment annual precipitation. About $55 \%$ of the total annual evapotranspiration is lost during winter season while the rest $45 \%$ is released in the summer season. This variation occurs due to 
low cloud cover, minimum relative humidity and longer time range in winter than summer season. As a result the winter evapotranspiration is higher than the summer.

According to the WetSpass simulated results of distributed annual evapotranspiration, its value ranges from 542 to $1482 \mathrm{~mm}$ in the catchment. The output annual evapotranspiration grid map (Fig 7) shows that low annual evapotranspiration is observed in northern, middle parts and southern parts of the catchment which receives lower annual rainfall. High evapotranspiration value is observed in eastern Lake Boyo area and southwestern highland of the catchment because these areas covered by cultivated crop, woodland, and also the presence of high rainfall in southwestern highland areas. Generally, the value of annual evapotranspiration of upper Bilate catchment varies with precipitation and land-use/land-cover. Hence, precipitation and landuse/land-cover are the main controlling factors of evapotranspiration in the catchment.

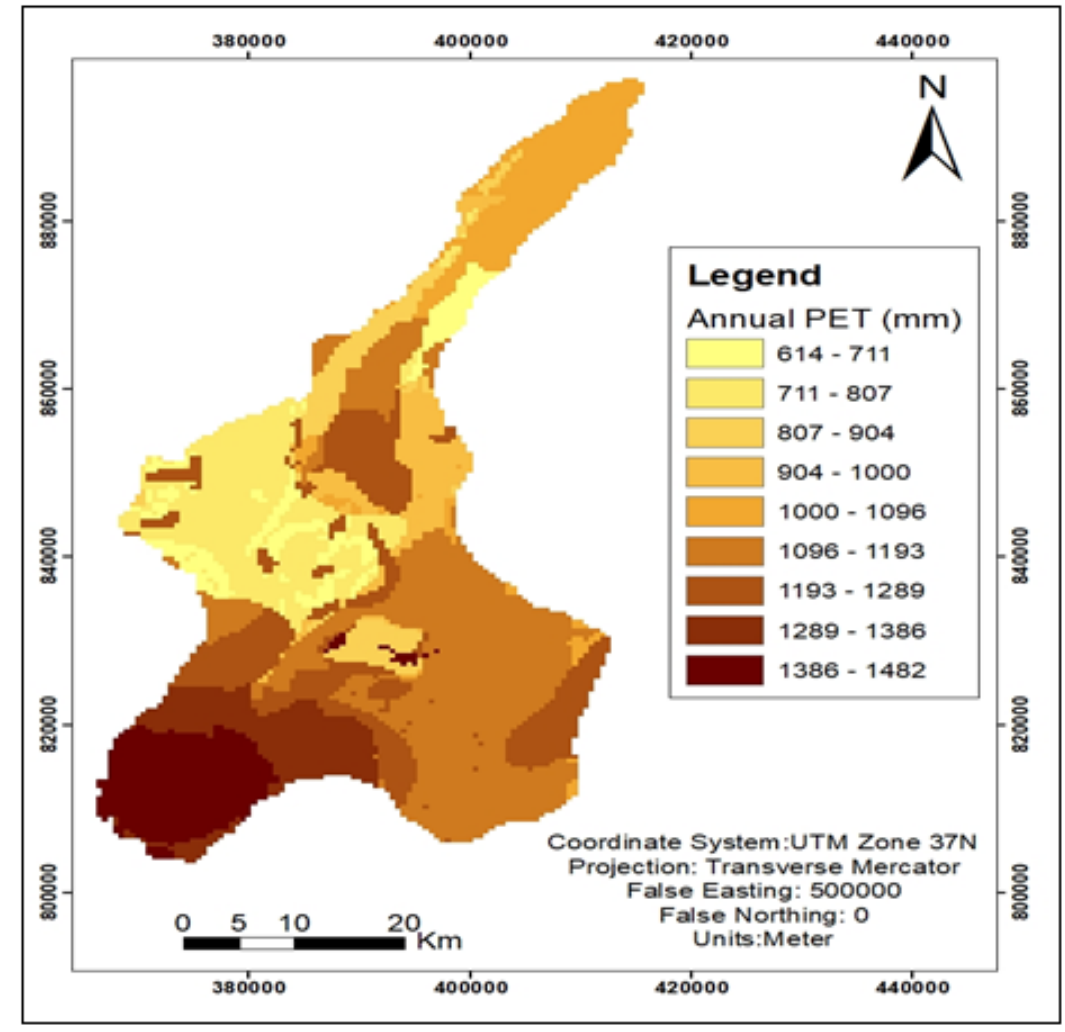

Figure 7. Annual evapotranspiration map of upper Bilate catchment.

\subsubsection{Surface Runoff}

To estimate the surface runoff of upper Bilate catchment WetSpass uses runoff coefficient which varies its value with vegetation, land use, soil type and slope. The surface runoff of upper Bilate 
catchment shows variation with land-use, soil type, slope, topography, precipitation and the other meteorological parameters (Fig 8).

The amount of surface runoff also shows variation in summer and winter season. The annual surface runoff in the upper Bilate basin ranges from 12 to $690 \mathrm{~mm}$ with 256 and $190 \mathrm{~mm}$ of mean and standard deviation value, respectively. The mean value represents $20.8 \%$ of the total annual precipitations. From this, about $54 \%$ of the surface run off occurs during the wet season (June to September) while the remaining $46 \%$ occurs during the dry season (October to May). This variation comes from rainfall difference in the two seasons. The amount of wet month's rainfall is higher than the dry months which exceed the infiltration capacity of the soil. This leads to high surface runoff. While in the dry months, the incoming rainfall is less than the infiltration capacity of the catchment's soils which leads to less surface runoff.

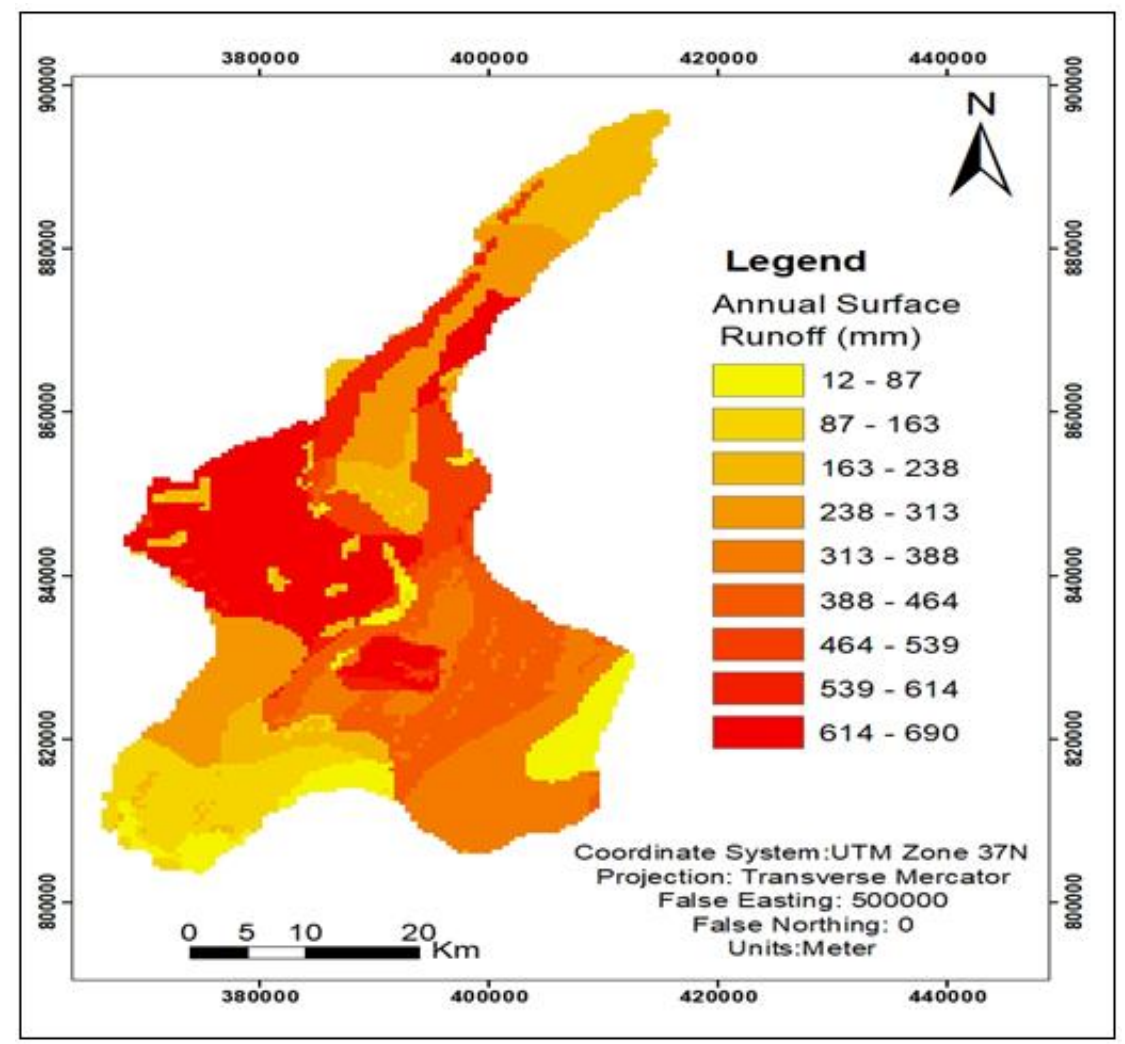

Figure 8. Annual surface runoff map of upper Bilate catchment.

According to the annually simulated surface runoff of the catchment (Fig 8), the north eastern part of the catchment, middle parts around Analemo, Shashogo Woreda and Lake Boyo area has highest surface runoff due to the high clay content of soil which has a low permeability 
that enhance for surface runoff. On the other hand, the northern high land parts around Alichoweriro, western high land area around Angecha, Durame, and southeast have less surface runoff. This is caused due to, clay loam and loam soil types associated with woodland and grass coverage of the area which hinder surface runoff. This shows that soil types have great impact on annual surface runoff of upper Bilate catchment in addition with land use/land cover. All landuse with, silty loam and loam soil yield the lowest surface runoff while agricultural land use types with sandy clay soil yield the highest amounts of surface runoff in the catchment.

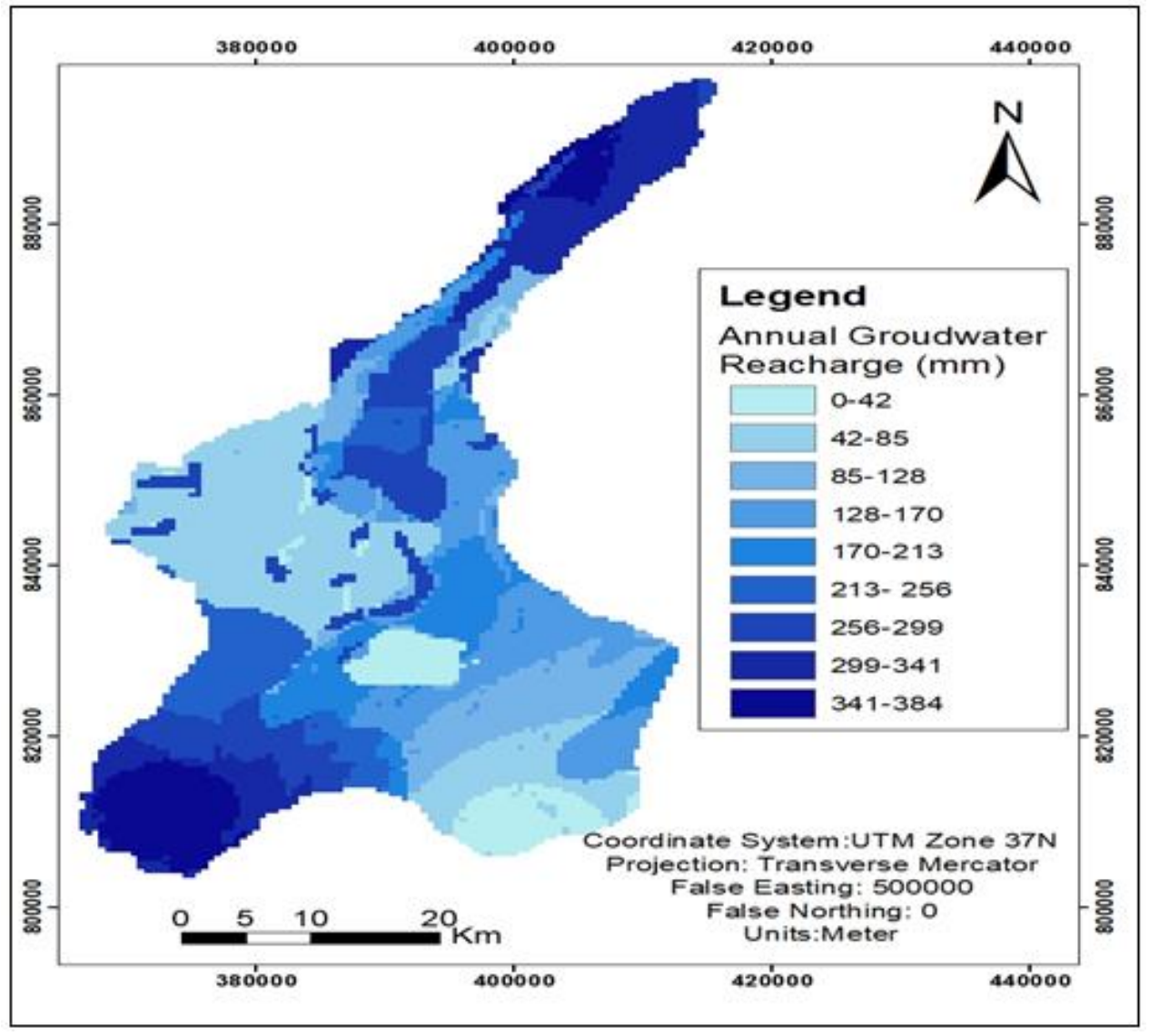

Figure 9. Annual groundwater recharge map of upper Bilate catchment.

\subsubsection{Groundwater Recharge}

There are different models to estimate recharge in a given area depending on actual areal conditions. In this case the WetSpass model estimates seasonal and annual long term spatial distribution amounts of groundwater recharge of upper Bilate catchment by subtracting the seasonal and annual surface runoff and evapotranspiration from the seasonal and annual precipitation, respectively. The annual groundwater recharge of upper Bilate catchment varies 
from 0 to $384 \mathrm{~mm}$ with $116 \mathrm{~mm}$ mean value (9.4\% of the annual precipitation). The result obtained has a similarity with the groundwater recharge estimated by Sinteyehu Legesse (2009) for upper Bilate which accounts $9.2 \%$ of the total precipitation using base flow separation and water balance approaches. $95 \%$ of the annual groundwater recharge of the catchment occurred during the wet season (summer) while the rest $5 \%$ is occurred in dry seasons (winter). The northern high land parts, south western parts near Mt. Amibercho and Mt. Dato around Angecha and Durame areas have high annual groundwater recharge due to the presence of permeable soils, high precipitation, deeply weathered and fractured volcanic rocks which are associated with tectonic activity and ultimately flow to the floor of the rift forming high discharge springs at the escarpment. On the contrary, the middle part of the catchment which covers Shashogo and Ana Lemo Woredas, eastern part around lake Boyo and southeast near Halabakulito have less amounts of recharge due to low precipitation, impermeable soils, morphology of land and overcrowded settlements. Moderate groundwater recharge has been quantified in loam, and silty loam soil in middle parts of the catchment around hosanna, Fonko, Shashogo Woreda and somehow southeast mountain parts of catchment (Fig 9).

In general, high values of groundwater recharge are observed in the wood land and cultivated crop land with silty loam and loam soils. This is due to good permeability of these soils and gentle slope topography. But, all types of soils with grazing lands-use areas have resulted low amounts of groundwater recharge. This is caused due to the release of higher amounts of transpiration through the plant and grass leaf stomata, respectively.

In open water bodies, such as in Lake Boyo and the surrounding area since the groundwater is on the lake surface, recharge value is zero.

\section{CONCLUSION}

In order to evaluate the groundwater recharge of the catchment, the land use, soil type, hydrometeorology, topography, slope and geology of the catchment has been investigated. Emphasis was made to collect primary field information and gather existing data to produce full information relevant for quantifying areal distribution of recharge and the other water balance component of the catchment.

The groundwater recharge estimation using WetSpass model has resulted a reasonably good estimation using limited data at relatively short period of time. The highly variable 
distributions of the climatic parameters associated with variations of land-use/land-cover, soil type, topography and slope are responsible for variations of the water balance element within the catchment.

The highest proportion of evapotranspiration and surface runoff for the catchment, relative to the groundwater recharge indicates that much effort is needed to change the environmental conditions of the catchment to enhance groundwater recharge by different mechanisms.

The groundwater recharge map along with other thematic maps can serve as a source of information database which can be updated from time to time by adding new information. Therefore there should be well organized data base system in different governmental organization so as to provide accurate data about the hydrogeological as well as hydrological systems for feature studies.

\section{ACKNOWLEDGEMENTS}

The authors would like to acknowledge the financial support by Addis Ababa University, school of earth sciences to conduct the research and the postgraduate study sponsorship given by the Hadiya zone water and mines bureau to the first author. National Meteorological Agency and Ministry of water and regional water bureaus are duly acknowledged for the data used in this work.

\section{REFERENCE}

Batelaan, O \& DeSmedt, F. 2001. WetSpass: a flexible, GIS based, distributed recharge methodology for regional groundwater modeling. Proceedings of a symposium held during the Sixth IAHS Scientific Assembly at Maastricht, The Netherlands, July 2001, IAHS Publication, 269:117p.

Batelaan, O \& Desmedt, F. 2007. GIS based recharge estimation by coupling surface-subsurface water balance. Journal of hydrology, 337: 337-355.

Fetter, C. W. 2001. Applied hydrogeology. $4^{\text {th }}$ Edition, ISBN: 0-13-088239-9, Prentice Hall, 598 p. 
Food and Agriculture Organization (FAO). 2003. The Digital Soil map of the world and derived soil properties, version 3.6. CD-ROM, information Division, FAO, Rome, Italy. Retrieved from http:/ www.fao.orglaglaglagll \dsmw.stm. on 14.03.2015.

Gebrerufael, H.K. 2008. Groundwater resource assessment through distributed steady-state flow modeling, Aynalem well field. Mekelle, Ethiopia. MSc Thesis, International Institute for Geo-Information Science and Earth observation Enschede, The Netherlands, 106p (https://www.itc.nl/library/papers_2008/msc/wrem/gebrerufael.pdf).

Geological Survey of Ethiopia (GSE), 2012. Geology, Geochemistry and Gravity Survey of the Hossaina area including Bilate. Report, GSE, Addis Ababa, Ethiopia (unpubl).

Kefale, T. 2012. Hydrogeological and Hydrochemical maps of Hossaina NB 37-2, AQATEST, Czech Republic.

Sintayehu, L. 2009. Integrated hydrogeological investigation of upper Bilate river catchment: Southern rift valley of Ethiopia. MSc Thesis, Addis Ababa University, Addis Ababa, Ethiopia, 111p (unpubl).

Shaw, E.M. 1994. Hydrogeology in practice, $3^{\text {rd }}$ Edition, ISBN: 0-203-01325-5, Taylor and Francis, 613p.

Yongxin, X \& Beekman, H. E (Ed.). 2003. Groundwater recharge estimation in Southern Africa. UNESCO IPH Series no.4, ISBN: 92-9220-000-3, Paris, 207p. 